Vorbereitungszentrum für

Entwicklungszusammenarbeit (V-EZ)

InWEnt gGmbH

(Capacity Building International)

Lohfelder 128

D-53604 Bad Honnef/Germany wissenschaftliche Arbeitsgemeinschaft

Afghanistan (AGA)

Afghanistan Research Group (ARG) e-mail: bglatzer $(a$ web.de

Bernt Glatzer

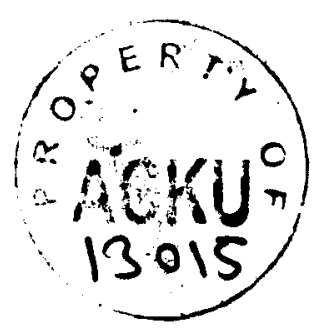

\title{
On the Anatomy and Fault lines of the Afghan Conflict
}

\author{
Outline of a paper presented at the Symposium \\ State Reconstruction and International Engagement in Afghanistan \\ Organised by the Centre for Development Research, Bonn University (ZEF) \\ And the Crisis States Programme, Development Research Centre. \\ London School of Economics (LSE)
}

Bonn, May 2003

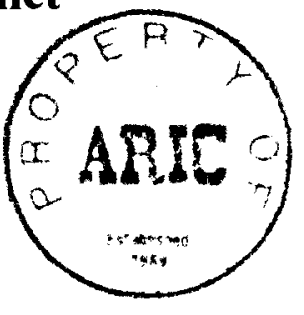

In autumn 2002 I was allowed to participate in a joint fact finding mission to Afghanistan of the German Agency for Technical Co-operation (GTZ), the Friedrich Ebert Stiftung (FES), and the German Working Group of Peace and Development (FriEnt). The aim was to identify the main lines of conflict, and to find answers for the following questions: which are the main forms of conflict and of political unrest, who are the main actors, and what are the actors' motives, aims, strategies and tactics. In addition we interviewed common people and victims of violence.

Another task of the team was to assess the chances of pacification and of non-violent conflict resolution, as well as the chance of the state to regain the monopoly on the use of force, and to make suggestions how the international aid community, particularly German agencies, can play a positive role in this respect.

The study is a continuation of an earlier conflict analysis by Uwe Kievelitz done in March 2002, and it stands in a series of similar studies by GTZ , FriEnt, and FES on Nepal, Sri Lanka, Guatemala, Columbia, Macedonia, Kosovo, and Usbekistan.

The results led to proposals to GTZ and FES how to optimise their project activities in such a way that German aid can contribute to a de-escalation of conflict and violence, and how it can share the international efforts to turn the country into a peaceful and safe place for almost 25 million people. The minimum purpose of such a study is to help avoiding unwanted social and political consequences of our actions, so that at least we do no harm.

After more than 20 years of international and internal wars on Afghan soil the home- grown institutions of conflict resolution that Afghans had developed over the centuries are not sufficient anymore to do the job. Since the 1970-s new causes of conflict have emerged and new structures, forms and techniques of violence and suppression were introduced that cannot be dealt with by traditional institutions. The Afghan wars since 1978 were imposed on the country to a large extent by outside forces, foreigners have actively and directly interfered, aggravated and prolonged the wars. We should not underestimate the role of Afghans in this mess, but the ongoing A fghan conflict cannot be analysed as a geographically limited phenomenon or as a system with boundaries, instead it has to be conceived as a fundamentally complex sub-system of an even more complex world-wide system of hegemonic politics, of Cold War, of post-Cold War relations and the New World Order, of global economic interests, and of international crime. Therefore, a conflict assessment focussed on Afghanistan only has limited analytical value.

Having said this, I will nevertheless focus on Afghanistan, the phenomena of conflicts are visible enough in Afghanistan, and the people are there and need our help there, even if the roots and causes of the problems lie outside as much as inside the country.

At this moment the larger part of Afghanistan looks rather peaceful and safe, the reports of fighting always come from the same limited areas. Today most villages and rural areas in Afghanistan give very much the same peaceful and archaic image as I remember from pre-war times. Only at a closer look one can detect that the type of crops have changed in very many places. But when talking to the people one quickly notices, that under the surface there is no peace, people do not trust the present peace process, and the fear is everywhere 
that open war and turmoil will break out in the moment foreign donors and protectors shift their attention to other places of crisis.

\section{Lines of Conflict}

We detected many more fields or lines of conflict than the following, but these seem to me the central ones:

- The Afghan Transitional Administration ATA (Kabul Government)

- Centre (Kabul) vs. periphery

- Regional centres vs. regional peripheries

- Politico-ideological conflicts

- Ethnicity

- Foreign interventions

- The grey economic sector and drugs

- The security sector

One of the main lines of conflict runs right through the cabinet of Karzai's Afghan Transitional Authority (ATA). On the one side stands a well organised minority of families from the Panjshir Valley north of Kabul, that holds the three most powerful ministries: Foreign Affairs, Defence and an important part of Interior. They control the army, the police and the secret service. On the other side stand President Karzai and representatives of various parties and groups who have fought and aligned with and against one another throughout the last decades, and who are not organised enough to form a counterweight against the immense power of the Panjshiri faction (Shora-ye Nazar).

This dismal picture of a torn government is not helpful to building up popular confidence in the state and the government.

The centuries' old antagonism between Kabul and the rest of the country continues even today. With its cosmopolitan urban culture Kabul developed little understanding of the world of nomads and peasants who on their part do not trust the Kabulis. For the people in the countryside Kabul was rather a Sodom and Gomorrah, and it was the centre of the state power which was always feared and watched from a safe distance. The dividing line between Kabul and the rest of the country is a obstacle to state integration.

The hinterland of Kabul is not homogeneous either, but has its own centres and peripheries. Regional centres are the cities of Herat, Kandahar and Mazar, to a lesser extent also Jalalabad Ghazni, Bamyan etc. The governors of the more important regional centres tend to extend their realms far beyond the limits awarded to them by the central government. Some of them, like e.g. Ismail Khan of Herat, control more financial resources than the central government and thus threaten the integrity of the state.

On the sideline are the regional peripheries: provinces without relevant political and economical centres , they form the backyard of the regional centres and are controlled by the latter, but not by Kabul. This situation seriously hampers the political integration of the state, leads to a growing imbalance of economical and political rehabilitation, and will end up in further impoverishment of large parts of Afghanistan. The other consequence is that these regional backyards develop into recruiting grounds for illegal militias, for criminal gangs and for backward oriented radical politico-religious groups. We should not forget that the Taliban were hatched in such an environment.

The regional centres are also breeding grounds for dubious political sub-cultures. In Herat civil rights are increasingly taken away from the people, particularly from the women, while in Jalalabad we could discern police terror and growing suppression of free expression. A remedy against these negative developments would be a drastic increase of aid for rehabilitation and development of the regional peripheries, deliberately bypassing the rulers of the regional centres.

In the countryside we could discover a solid Afghan national identity. But that must not be confused with state awareness. People identify themselves strongly with Afghanistan and with the common fate of the Afghans during the protracted war, ethnic identities seem to be of lesser importance, but there are only very vague notions of state and of what a state and its institutions are good for. This lack of civil awareness is not a good basis for the up-coming general elections in 2004. The team finds it necessary that not only certain UN organisations, but that all national and international organisations and actors who are presently active in Afghanistan launch a huge joint information campaign all over Afghanistan to explain to the people what the election is for, what is a state, what are its functions, the duties of its representatives and of the candidates after being elected. For this purpose it would also be necessary that the present Kabul government is given a chance to show more presence in the countryside. 
Ethnic boundaries are often grossly over-emphasised by foreign observers. One should not mistake ethnic units as "real", definable and immobile socio-political groups. In the context of the Afghan conflict ethnicity is deliberately utilised and manipulated by political entrepreneurs, according to situational opportunity. Ethnicity provides the opponents and their parties in a conflict situation with feelings and emotions of imaginary common descent, evoking strong feelings of solidarity, of "we" and "they". Since long warlords have discovered ethnicity as an ideal tool to motivate fighters. If combined with religious fervour ethnicity can be irresistible.

In fact none of the present conflicting parties we know of is fighting for ethnic dominance or for other "traditional" or "irrational" values, but all are after political power, influence and material resources for their leading figures..

A future state, a generally acceptable government, administration and army must be based on a broad representation of the whole population, but it would be a heavy mistake to base that representation quantitatively on ethnic proportions. That cannot function, because ethnic groups in Afghanistan are no distinct social and political groups, they are not definable objectively and have never been counted in a way than any relevant number of Afghans could agree upon. It would al so be a recipe for disaster if aid would be distributed along ethnic criteria. This would create new injustice, it would open a Pandora's box and would thus producewhat it tried to avoid: new ethnic hatred and conflict.

The battle against illegal economic activities, such as drug production, drug trade, gun running and smuggle is still on the agenda of international agencies, but not pursued wholeheartedly. Germany is the lead nation for rehabilitating and developing the Afghan police. It is yet to be seen whether the police is really given the technical equipment, the training and sufficient money to pay salaries, and enough political support to combat the world's largest opium and heroin industry. First of all the police needs to become politically neutral in order to win acceptance and legitimacy in the eyes the Afghan population outside the Panjshir Valley. It is not yet clear to me to which extent the new interior minister Ali Ahmad Jalali is successful in this task. If not, the police will remain for most Afghans the problem rather than the solution.

The neighbours Pakistan and Iran each continue their heterogeneous policy towards Afghanistan. Pakistan cannot prevent her own radical political religious groups from interfering in Afghanistan, particularly since islamists have taken over the provincial government of the NWFP, and the moderate Iranian President Khatami is obviously not in full control of the political and ideological border traffic between the two countries. Only heavy international pressure can prevent Iranian and Pakistani political and radical elements from further destabilising Afghanistan.

All observers share the opinion that Afghanistan needs a national army in order to regain the monopoly on the use of force in the state. So far this could not be achieved, instead private illegal militias are mushrooming and may become armies of civil war if no sufficient measures are taken. Governors, local security chiefs and even army officers misuse funds of the official army to finance their own militias. Everybody demands "DDR" (Demobilisation, Disarmament and Reintegration), but little can be seen of the integration of the militias into the national army or of their demobilisation, disarmament and integration into the ranks of the civilian population.

At the donors conference in Tokyo in January 2002 Japan opted for becoming the lead nation for DDR. However, in the team's opinion, at least the Reintegration part of it should be the main goal for all aid across the various sectors to which the other nations have subscribed. Although we have not done a sound survey on this particular point there are indications that make us believe that there is a general readiness among members of the militias to make the transition to a civilian live. All they need are opportunities to build for themselves and their families a civilian existence. They need realistic chances for their future, not just shortterm jobs in a project. Most of them cannot just go back to the farms or workshops of their parents, because the Afghan population has grown by about 50 percent since before the war. These 50 percent cannot survive on the same resources and techniques as the pre-war population.

International projects of aid and development should be scrutinised as to whether they can contribute to offering to young Afghans a sustainable chance of survival by legal means in their own country. I think here lies the key for future security in Afghanistan without which all ather projects become meaningless. 


\section{Actors and Actions}

It helps our understanding of Afghanistan if we see the main actors of conflict as entrepreneurs in a war economy (Barnett R. Rubin 2000) or in a market of violence ("Gewaltmarkt", Georg Elwert 2001). Free from state laws and ethic restraints the entrepreneurs of this war economy pursue their personal accumulation of power, might and influence on the various social and local levels. Success means here the appropriation of a maximum of personal power and control over a maximum of human and material resources. These resources are convertible as in any market economy. However, to my understanding the final aim in this market game, at least for the big players, is not money but power and dominance. A warlord for example may spend money to buy power, but he will not sell power for money. In this respect a warlord is comparable to the traditional khan who is ready to spend his last Afghani in order to maintain his political position.

At least the networks and fields of action of warlords, commanders, politicians, party leaders, drug barons, gun runners, smugglers and timber Mafiosi can be explained to a good deal by such a market model, better than by such notions as tradition, religion, or ethnicity. These "irrational" factors actually do come in, but only as chips in a game used very rationally to charge ones own followers with emotions in order to make them do things that are harmful to them but useful for the entrepreneur.

However, I am not too pessimistic. As Mark Sedra (2003) emphasises we have more and less intelligent players in the war game. The "total spoilers" and the "partial spoilers".

I have reasons to believe that not all participants in the market of violence calculate with a perpetuation of the present situation. It is my hypothesis that the more intelligent war lords and commanders are aware of the fact, that a central state with a monopoly on the use of force will come sooner or later and that their only chance of political survival is to adjust in time to that future, i.e. to secure a good position in a future state. The present activities of many commanders and warlords to invest in private militias may also be seen in this context. In their view only those who can argue from a background of strength will have good chances to gain prominent positions in a future state.

I see the severe problems connected with integrating the warlords into the future state, particularly those who have committed crimes against humanity, but at the present situation there may be little alternatives. The warlords are out there and we cannot just wish them away. I doubt there is a Guantanamo waiting for them. "Total spoilers" (to use Sedra's term) such as Hekmatyar of course are out of the state game. I hope the Afghans themselves will find a way how to get rid of this menace, ideally through a legal tribunal, but that leads us to a further discussion beyond the scope of this paper.

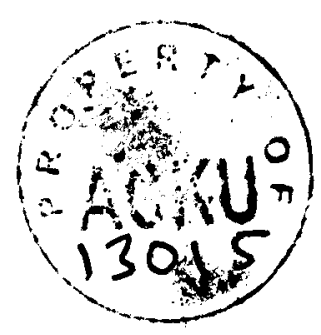

